\title{
2019 Dissertation List
}

A

PSA is pleased to include here the names of individuals who have completed their doctoral dissertations at political science departments in the United States during the 2019 calendar year. In order to provide the most accurate information possible, this list is based on data reported directly from departments.

Daniela Stevens, American University: Interest-Based Explanations of the Stringency of Carbon-Pricing Policies: Three Analytical Approaches

Puneet Bhasin, Brown University: Sustaining Financializations: Politics and Profits in the Financial Transformation of Economies

Poulomi Chakrabarti, Brown University: One Nation, Many Worlds: Varieties of Development Regimes in India

Ryan Emenaker, Brown University: Judicial Evaluation \& Democracy: The Democratic Form of Judicial Review

Paul Gutierrez, Brown University: The Invisible Hand of the State: Corporation, Police, and Economy

Rajeev Kadambi, Brown University: Politics and the Spiritual: Reading Gandhian, Buddhist, and Humanist Ethical Traditions

William Kring, Brown University: Contesting the International Monetary Fund? Regional Battles for Global Liquidity

Jerome Marston, Brown University: To Stay or Flee? Displacement due to Gang Violence in Medellin, Colombia

Rebecca Bell Martin, Brown University: The Politics of Violence: Empathy and Action During Conflict

Rachel Meade, Brown University: The People Against the Elites: Populist Identity in the US and Argentina

Timothy Turnbull, Brown University: The Sources of US Trade Sanctions

Marcus Walton, Brown University: Resources \& Recourses: The Origins of Entitlement in Egypt, Nigeria, and South Africa
Cadence Willse, Brown University: Private Funding, Public Schools: Interest Group Mobilization, the Changing Advocacy Agenda, and Public Education

Joshua Miller, The Catholic University of America: The Politics of Race and the Development of the Law and Order President

Samuel Sprunk, The Catholic University of America: Isiah Berlin: Machiavellian Liberal

Artour Aslanian, Claremont Graduate University: Using a Mixed Methods Approach to Study the Evolution of Party Platforms, 1960-2016

Jake Campbell, Claremont Graduate University: Divvying Up Dollars: Budget Allocation Game Experiments and the Impact of Policy-Relevant Information on Stated Preferences for Public Spending.

Khaled Eid, Claremont Graduate University: A Tacticians's Guide to Conflict, Vol. 1: Methods on Explanation and Prediction of Intrastate Conflict

Lisa Jene, Claremont Graduate University: Three Essays on Africa

Ben Judge, Claremont Graduate University: Here Am I: William Howard Taft and the Philippines

Aye Aye Khaine, Claremont Graduate University: Assessing the Values of Nutrition-Sensitive Programs in Improving the Outcomes of Children: Evidence from Myanmar

Faizan Khan, Claremont Graduate University: Application of Agent-Based Modeling: Simulating Financial Systemic Risk and Contagion within Housing and Financial Markets
Simon Tang, Claremont Graduate University: MSMEs (Microsoft, Small and Medium Enterprises) and Democracy, a Panel Data Model

Cheng-Han Tsai, Claremont Graduate University: The Role of Uncertainty in Inter-State Conflicts: 1816-200o

Michael Angstadt, Colorado State University: Green Courts and Global Norms: Specialized Environmental Courts and the Global Governance of Environmental Challenges

Chelsea DeCarlo, Colorado State University: Re-imagining the Ecological Subject: Toward a Critical Materialism of Entangled Ecologies

Kolby Hanson, Columbia University: Rebel Organizations in Crackdown and Truce

Katharine Jackson, Columbia University: Corporate Autonomy: Law, Constitutional Democracy, and the Rights of Big Business

Sarah Khan, Columbia University: Making Democracy Work for Women: Essays on Women's Political Participation in Pakistan

Jacob Kopas, Columbia University: Legitimizing the State or a Grievance?: Property Rights and Political Engagement

Summer Lindsey, Columbia University: Women's Security After War: Protection and Punishment in Eastern Democratic Republic of Congo

Erik Lin-Greenberg, Columbia University: Remote Controlled Restraint: The Effect of Remote Warfighting Technology on Crisis Escalation

Aslihan Saygili, Columbia University: Democratization, Ethnic Minorities and the Politics of Self-Determination Reform 
Dane Thorley, Columbia University: Essays on Courts, Randomization, and Experiments

Camila Vergara Gonzalez, Columbia University: Assembling the Plebeian Republic: Popular Institutions against Systemic Corruption and Oligarchic Domination

Joonseok Yang, Columbia University: Three Essays on the Political Economy of Business Mobility: Electoral and Policy Implications of Business Location Decisions

Aaron Zubia, Columbia University: The Making of Liberal Mythology: David Hume, Epicureanism, and the New Political Science

David de Micheli, Cornell University: Back to Black: Racial Reclassification and Political Identity Formation In Brazil

Vijay Phulwani, Cornell University: From Order to Organizing: Rethinking Political Realism and Democratic Theory

Whitney Taylor, Cornell University: Creating a Sense of Obligation: Legal Mobilization for Social Rights

Edward Quish, Cornell University: Beyond Populism: Radical Democracy and the Politics of Cooperation

Youyi Zhang, Cornell University: Political Economy of Chinese State-Owned Enterprises: Risky Investment in the Developing World

Maxwell Burkey, CUNY Graduate Center: The Counter-Patriotic Tradition in American Politics: Resistance, Nationhood, and Democracy

Elena Cohen, CUNY Graduate Center: Dangerous Exhibitions: Erotic Justice and Comparative Constitutional Law

Eli Karetny, CUNY Graduate Center: Ungodly Freedom: How Philosophers Rise and Empires Fall in the Work of Leo Strauss
Jason Kropsky, CUNY Graduate Center: Between Politics and Morality: Hans Kelsen's Contributions to the Changing Notion of International Criminal Responsibility

Pierre Losson, CUNY Graduate Center: Claiming the Remains of the Past: The Return of Cultural Heritage Objects to Colombia, Mexico, and Peru

Nicholas Micinski, CUNY Graduate Center: Coordination, Collaboration, and Delegation in EU Migration Management

Nicholas Pehlman, CUNY Graduate Center: Police Reform in Ukraine Since the Euromaidan: Police Reform in Transition and Institutional Crisis

Amy Schiller, CUNY Graduate Center: Caring Without Sharing: Philanthropy's Creation and Destruction of the Common World

Pamela Whitefield, CUNY Graduate Center: The Diffusion of a Movement Moment: Labor Organizing in the Shadow of Occupy Wall Street

Chong Chen, Duke University: Rebel Interdependence: Essays on Ethnic Mobilization, Competition, and Inclusion

Haohan Chen, Duke University: The Micro-foundations of Authoritarian Rule Unveiled by Digital Traces: New Theories and Methods with Applications to Chinese Social Media

Eric Cheng, Duke University: Hanging Together: A Liberal Democratic Theory of Political Friendship for Troubled Times

Noa Cnaan-On, Duke University: The Political Economy of Religious Organizations: A Network-Based Explanation for Government Allocation of Resources

Trang Anh Do, Duke University: Brain Drain or Gain? Skilled Migration and Human Capital Accumulation in the Developing World

David Kearney, Duke University: Ties that Bind: Connections, Institutions and Economics in the People's Republic of China
Antong Liu, Duke University: The Modernization of Honor in EighteenthCentury Political Theory

Hao Liu, Duke University: The Politics of Protest and State Repression in Authoritarian Regimes.

Bailey Sanders, Duke University: Partisan Bridging and its Gendered Dimensions

Nura Sediqe, Duke University: Ummah : The Identity Negotiations of Muslims in the United States

Jeremy Spater, Duke University: Identities, Proximity, and Mobilization in Indian Slum Neighborhoods

Juan Tellez, Duke University: Three Essays on the Dynamics of Conflict in Civil Wars

Jan Vogler, Duke University: The Political Economy of Public Bureaucracy: The Emergence of Modern Administrative Organizations

Kaitlyn Webster, Duke University: Rethinking Civil War

Joshua Fjelstul, Emory University: Papers on the Political Economy of the European Union

Anna Gunderson, Emory University: Why Do States Privatize their Prisons? The Unintended Consequences of Inmate Litigation

Laura Huber, Emory University: Buying Women's Rights: The Role of Conflict and International Actors in Gender Reform

Bethany Morrison, Emory University: Naming, Blaming, and Calculating: Understanding Who Files

Yeon (Grace) Park, Emory University: Domestic Politics and International Bargaining

Adam Howe, Florida International University: How State Capacity Matters: A Study of the Cooptation and Coercion of Religious Organizations in Southeast Asia and Beyond 
Zachary Karazsia, Florida International University: Genocide in the Modern Age: State-Society Relations in the Making of Mass Political Violence, 1900-2015

Orcun Selcuk, Florida International University: Populism and Leader Polarization in Venezuela, Ecuador, and Turkey

Alexis Blanc, George Washington University: Conventional Theater Missile Defense and Crisis Behavior

Aleksandr Fisher, George Washington University: Manufacturing Dissent: The Subtle Ways International Propaganda Shapes Our Politics

Bryce Loidolt, George Washington University: A Delicate Balance: Security Force Assistance, Military Advising, and Recipient Unit Military Effectiveness

Elizabeth Pertner, George Washington University: Media Moguls and Political Patrons: Media and Democracy in Turkey, 1980-2018

Mara Pillinger, George Washington University: Re-fit for Purpose? The Ritual of Reform in Global Health Partnerships

Phillip Wininger, George Washington University: Courts in Transition: Essays on the Politics of Judge Selection in the States

Rebekah Dowd, Georgia State University: The Development of Digital Human Rights in the European Union: How Key Interests Shape National and Regional Data Governance

Richard Gardiner, Georgia State University: Judicial Elections and the Separation of Powers

Kristina LaPlant, Georgia State University: The Heart of Politics: A Typology of Gender Stereotypes in Campaign Advertisements and Analysis of Emotional Reactions among Voters

Matthew Montgomery, Georgia State University: Public Attention and Certiorari: The Impact of Public Attention on Supreme Court Petitions
Adnan Rasool, Georgia State University: Bargaining a Democracy: Bureaucratic Quality and Democratization

Jacob Abolafia, Harvard University: Penal Modernism Before Modernity: Correction and Confinement in the History of Political Thought

Christopher Carothers, Harvard University: Combating Corruption in Authoritarian Regimes

Christopher Celaya, Harvard University: The Efficacy of Deliberative Democracy

Rushabh Doshi, Harvard University: The Long Game: Chinese Grand Strategy after the Cold War

Chase Foster, Harvard University: The Politics of Delegation: Constitutional Structure, Bureaucratic Discretion, and the Development of Competition Policy in the United States and the European Union, 1890-2017

Huan Gao, Harvard University: Spatial Control and State Power in Disasterstricken Cities

Rebecca Goldstein, Harvard University: Essays on the Politics of Policing

Yichen Guan, Harvard University: Engagement under Authoritarian Rule: Political Participation of Muslim Minorities in China

Jesse Gubb, Harvard University: Reassessing the President's Administrative Powers

John Harpham, Harvard University: The Intellectual Origins of American Slavery

Dana Higgins, Harvard University: The Essential Role of Simultaneous Interventions in Civil Conflict Resolution

Jennifer Howk, Harvard University: Too Dysfunctional to Govern: Trauma Capital and State Retreat in Rural Alaska

Connor Dezzani Huff, Harvard University: Why Rebels Reject Peace
Aaron Kaufman, Harvard University: Essays on the Applications of Machine Learning and Causal Inference in American Politics

Tsin Yen Koh, Harvard University: Killing the White Bull: Eassays on Bentham on Sex and Religion

Mayya Komisarchik, Harvard University: Essays on Race and Representation in American Politics

Dominika Kruszewska, Harvard University: From the Streets to the Party Lists: Electoral Advantages of Social Movement Activism

Belen Fernandez Milmanda, Harvard University: On the Ballots, In the Streets or Under the Table: Agrarian Elites' Political Strategies in Latin America

Daniel Moskowitz, Harvard University: Context and Accountability: How the Informational and Partisan Contexts Shape Voter Behavior and Representation

Shanna Weitz, Harvard University: Essays on Economic Segregation and Local Public Goods

Tess Wise, Harvard University: Economic Insecurity and American Political Culture: A Case of Middle-Class Americans Going Through Personal Bankruptcy

Stefan Carpenter, Indiana University: Unpacking the Efficacy of CommunityBased Wildfile Governance: The Influence of Economic Benefit Types, Risk, and Heterogeneity on Collective Action

Zach Goldsmith, Indiana University: An Oppressive Passion: Kant, Burke, and Dostoevsky on the Problem of Fanaticism

Paul Hoffman, Indiana University: The Mismanagement of Savagery: Understanding Violent Political Organization Target Preferences in Iraq, 2003-2014.

Defne Jones, Indiana University: Democratization or De-Democratization: The Role of Civil Society in Mass and Elite Interactions 
Wynand Kastart, Indiana University: Regime Legacies and Domestic Peace: Evidence from Latin America

Yehuda Magid, Indiana University: Explaining the Occurrence and Dynamics of Dominant Group Violence: Uncertainty, Threat, and Israeli Settler Violence in the West Bank

Brandon Miliate, Indiana University: Grounded Understandings: The Meaning and Origins of Ethno-National Demands for Autonomy at the Intersection of India, Bangladesh, and Myanmar

Timothy Model, Indiana University: The Logic of Anti-Corruption Campaigns

Zongyuan Liu, Johns Hopkins University SAIS: Sovereign Leveraged Funds and Financial Statecraft: A Comparative Analysis of China and Japan

Douglas Winton, Johns Hopkins University SAIS: Is Urban Warfare a Great Equalizer?

John Boersma, Louisiana State University: Aristotle's Quarrel with Socrates: Friendship in Political Thought

Angela McCarthy, Louisiana State University: The Religious Impact: Understanding the Influence of Religiosity on Attitudes Toward Policy Issues

Cory Sukala, Louisiana State University: A State of Impermanence: Buddhism, Liberalism, and the Problem of Politics

Michael Toje, Louisiana State University: Political Parties for Protection and Profit: Explaining Opposition Party Competition under Electoral Authoritarianism

Bertha Vitela, Louisiana State Univesity: Money In and Money Out: The Effects of Race and Gender on Campaign Finance

Kirstie Dobbs, Loyola University Chicago: Active on the Street But Apathetic at the Ballot Box? The Voting Behavior of Tunisian Youth (2011 to Present) in a Comparative Perspective
Ratri Istania, Loyola University Chicago: Administrative Unit Proliferation and Ethnic Group Conflict: Does the Prospect of a New Province Mitigate Ethnic Group Conflict?

Camila Andrade Gripp, The New School for Social Research: New Dogs, Old Tricks: The Inner Workings of an Attempt at Police Reform in Rio de Janeiro, Brazil

Jong Wan Baik, The New School for Social Research: Politics of Dualism: A Study of Active Labor Market Policies in South Korea

Yunjeong Choi, The New School for Social Research: The Boundary Problem of The People: A Democratic Theory of Constituent Power

Chris Crews, The New School for Social Research: Social Movements and Earthbound People: Towards a New Politics of the Earth in the Anthropocene

Antonia Cucchiara, The New School for Social Research: Civis Americanus Sum Luigi Antonini, the Italian-American Labor Council and the Movement to Reclassify Italian Alien Enemies During World War II

Geeti Das, The New School for Social Research: From Mental Disorder to Emotional Data: Epistemic Power Over Sexual Politics

Mario Marcello Pasco Dalla Porta, The New School for Social Research: The Coercion/Dialogue Paradox in Contentious Dynamics: A Comparative Analysis of Mining-Related Conflicts in Latin American Countries

Mariana Prandini Fraga Assis, The New School for Social Research: Boundaries, Scales and Binaries of Women's Human Rights: Feminist Confrontations in the Transnational Legal Sphere

Christopher Harris, The New School for Social Research: Political Acts, Generational Minds: Race, Culture and the Politics of the Wake
Veronica Alicia Zebadua Yanez, The New School for Social Research: Feminist Theory and the Experience of Freedom: Thinking with Hannah Arendt and Simone de Beauvoir

Sirojuddin Arif, Northern Illinois University: Farmers, Workers, and State Responses to the Food Crises: State/ Society Conflicts and the Politics of Agriculture Development in Indonesia and Nigeria

Erica Ceka, Northern Illinois University: Understanding Network Performance: The Case of IL 9-1-1 Emergency Call Service

Anthony Cooling, Northern Illinois University: The Second Amendment, Court Decisions, Political Culture, and Significant Social Change

Nicole Loring, Northern Illinois University: The Roadmap to Liberalization: Myanmar's Transition from Military to Civilian Rule

Jessica Edry, Rice University: Domestic Politics, NGO Activism, and Global Cooperation

Heather James, Rutgers University: Still Running Backwards and in High Heels: Female Candidate Fundraising Process, Perception, and Challenges in the 50 States

Gregory Lyon, Rutgers University: Labor Market Institutions and Political Engagement in the US

Abbas Fadhil Mahmood Alketeshi, Rutgers University: Electoral Mobilization and Voter Turnout in PostAuthoritarian Countries: The Case of Parliamentary Elections in Iraq (2005-2018)

Kyle Morgan, Rutgers University: Is Anyone Worried About Judicial Review? Attitudes Towards Judicial Review in an Era of Political Turmoil

Mary Nugent, Rutgers University: When Does He Speak for She? Men Representing Women in Parliament 
Sevinc Ozturk, Rutgers University: Foreign Aid Allocation by Autocratic and Illiberal Regimes: Influence and Competition of Business Elites

Michael Richards, Rutgers University: Dystopophobia: Aversion to the Worst in the Philosophy of Thomas Hobbes, Edmund Burke, and Karl Popper

Bailey Socha, Rutgers University: Welfare Behind the Wall: The Bureaucratic Origins and Development of Correctional Education in the United States, 1915-2012

Catherine Wineinger, Rutgers University: Gendering the GOP: Rhetoric, Representation, and Republican Congresswomen as Party Messengers

Kirk Bansak, Stanford University: Essays in Political Methodology

Alexandra Blackman, Stanford University: The Politicization of Faith: Settler Colonialism, Education, and Political Identity in Tunisia

Andrew Brooks, Stanford University: The Creation and Impact of British Colonial Armies in Africa

Mathilde Emeriau, Stanford University: When Bureaucratic Discretion Leads to Discrimination: Evidence from France

Jane Esberg, Stanford University: Strategies of Repression in Pinochet's Chile

Maria Krupenkin, Stanford University: Essays on Partisan Polarization

Iris Malone, Stanford University: Insurgency Formation and Civil War Onset

Lachlan McNamee, Stanford University: Demographic Engineering

Kevin Mintz, Stanford University: SexPositive Political Theory: Pleasure, Power, Public Policy and the Pursuit of Sexual Liberation

Rebecca Perlman, Stanford University: Precaution in The Private Interest

Benjamin Schaftel, Stanford University: Public Confidence in the US Military
Bradley Spahn, Stanford University: Before the American Voter

Shea Streeter, Stanford University: The Racial Politics of Police Violence in the United States

Edgar Franco Vivanco, Stanford University: Strategies of Indigenous Resistance and Assimilation to Colonial Rule

John Young, Stanford University: Liberty and Democracy in the Metropolis

Giles David Arceneaux, Syracuse University: Beyond the Rubicon: Command and Control in Emerging Nuclear Powers

Abolghasem Bayyenat, Syracuse University: State Identities and Foreign Policy Change: The Logic and Political Dynamics of Iran's Nuclear Policy-Making, 2002-2015

Sinan Chu, Syracuse University: Policy Subsystem, Knowledge Community, and Scholarly Discourse in Ethnic Policy-Making of Post-Mao China

Esra Issever Ekinci, Syracuse University: Party Competition and Electoral Reforms in Parliamentary Democracies

Evan Laksmana, Syracuse University: The Imitation Games: Military Institutions and Westernization in Indonesia and Japan

Li Shao, Syracuse University: The Power of Protest Messages: An Information Model on Protest Participation in China

Catriona Standfield, Syracuse University: Gender and Legitimacy in United Nations Meditation

Amanda Alvarez, Temple University: Risk Acceptance and Contentious Politics: An Understanding of Protest Activity in Latin America

Jeff Antsen, Temple University: Why Bother Choosing Anyway? The Framing Dynamics behind Narratives of Queer Etiology

Claire Gothreau, Temple University: The Political Consequences of Gender-Based Marginalization
Caroline Tynan, Temple University: Diversionary Discourse: A Historical Comparison of Saudi Interventions in Yemen

Heather Galligan Bennett, University at Albany, SUNY: Winners and Losers in the Remaking of American Healthcare Payment Systems Following the ACA: A Theory of Private-Actor Policymaking and Implications for Democratic Decision Making

Injeong Hwang, University at Albany, SUNY: Foundation for Success: Radical Right Populist Parties' Strategic Use of the European Parliament

Sean McKeever, University at Albany, SUNY: Adorno's Concept of the Good: Peaceful Tensions and the Precipice of Paradise

Joshua Newman Caldon, University at Albany, SUNY: The Hot and the Cold: A Historical Explanation for Russia's and America's Contrasting Foreign Policy Approaches to the Arctic

Yi-hao Su, University at Albany, SUNY: Sanctions-Busting and the Signing of New Preferential Trade Agreements and Bilateral Investment Treaties

Tiffany Chu, University of Arizona: The Influence of Host and Origin Country Dynamics on Refugee Journeys

Tingjia Chen, University of Arizona: Principal Moral Hazard, Environmental Regulatory Biases, and Strategic Interaction among the Chinese Local Governments

Sangmi Jeong, University of Arizona: Negotiation in the Street: Protests, Regime Type, and International Bargaining Outcomes

Georgia Pfeiffer, University of Arizona: Understanding Advocacy Coalitions: Coordination and Belief Segregation in the United States Environmental Risk Management Subsystem

Samaila Adelaiye, University at Buffalo: Foreign Investments and Third-party Diplomatic Intervention in Armed Conflict 
Abdulaziz Almuslem, University at Buffalo: Civil Conflict: A Three-Part Study on Fostering Durable Peace

Collin Anderson, University at Buffalo: The Influence of State-Run Media on Civil War Severity

Kevin Stout, University at Buffalo: Pol in the Family: The Effects of Dynasties in Congressional Elections and Representation

William Callison, University of California, Berkeley: Political Deficits: The Dawn of Neoliberal Rationality and the Eclipse of Critical Theory

Alice Ciciora, University of California, Berkeley: Strength without Numbers: The Political Influence of European Farmers

Thomas Kelly, University of California, Berkeley: Political Strategies of Labor \& Business: The Case of Prison Privatization

Adam Lichtenheld, University of California, Berkeley: Population Displacement Strategies in Civil War

Andrew Manson, University of California, Berkeley: Biased Advice, Ideology and the Development of Nixon's Foreign Policy

Andrew McCall, University of California, Berkeley: Essays on Structural Racism in US Municipal Law Enforcement

Nathan Pippenger, University of California, Berkeley: Anxieties of Membership: American Citizenship after Democratic Nationalism

Jason Poulus, University of California, Berkeley: Essays on the Political Economy of the American Frontier

Andrew Reddie, University of California, Berkeley: Governing Insecurity: The Design and Effect of Arms Control Agreements

Andres Schipani, University of California, Berkeley: Strategies of Redistribution: The Left and the Popular Sectors in Latin America
Paul Thissen, University of California, Berkeley: Legacy Institutions and Political Order in Weak States: Evidence from Chad

Guadalupe Tunon, University of California, Berkeley: When the Church Votes Left: The Electoral Consequences of Progressive Religion

Rosemarie Wagner, University of California, Berkeley: Laws Living and Armed: The Legal \& Political Theory of Thomas Hobbes

Taylor Carlson, University of California San Diego: Through the Grapevine: Essays on the Consequences of Interpersonal Political Communication

Lauren Ferry, University of California, San Diego: Who Wins? The Political Economy of Sovereign Debt Restructuring

Andrew Janusz, University of California, San Diego: Race and Political Representation in Brazil

Heidi McNamara, University of California, San Diego: Who Gets In? Nonstate Actor Access at International Organizations

Brandon Merrell, University of California, San Diego: Leaders, Audiences, and the Use of Force

Stan Oklobdzija, University of California, San Diego: Dark Money and Political Parties After Citizens United

Inbok Dennis Rhee, University of California, San Diego: Between Constituents and the Capital: Understanding African Legislators

Abigail Vaughn, University of California, San Diego: Geopolitics and the 21st Century Global Financial Safety Net

Louis Weimer, University of California, San Diego: Consanguinity and Intimate Partner Violence

Christopher Faulkner, University of Central Florida: The Causes, Dynamics, and Implications of Child Soldiering
Joseph Funderburke, University of Central Florida: National Security and Rising Partisan Polarization

Didara Nurmanova, University of Central Florida: Exogenous Shocks and Political Unrest

Leah Dean, University of Cincinnati: Overcoming Healthcare Polarization with Interaction: Effects of the Affordable Care Act in Kentucky

Albert Klein, University of Cincinnati: Dona Nobis Pacem: Occupied Before Jus Post Bellum?

Fabian Arzuaga, University of Chicago: Paradoxes of Individuality: Liberalism, the Crisis of Work, and the Critique of Political Economy

Yuna Blajer de la Garza, University of Chicago: A House is Not a Home: Citizenship and Belonging in Contemporary Democracies

Eric Chase-Sosnoff, University of Chicago: The Effect of Perceived Discrimination on Authoritarianism Among Stigmatized Racial Minorities: A Multi-Level Analysis

Samuel Galloway, University of Chicago: Cruising Politics: Affect, Assemblage, Agonistic Democracy

Alfredo Gonzalez, University of Chicago: Other than Honorable: The Rise and Decline of Citizenship-for-Service, 1918-1965

Mariya Grinberg, University of Chicago: Planning for the Short Haul: Explaining Wartime Trade Between Enemies

Tania Islas Weinstein, University of Chicago: Politics in a House of Mirrors: Art, Nationalism, and Representation in Contemporary Mexico

Jennifer Jackson, University of Chicago: Race, Risks, and Responses: Mapping Black Americans' Reactions to Group Threat

Sana Jaffrey, University of Chicago: Leveraging the Leviathan: Politics of Impunity and the Rise of Vigilantism in Democratic Indonesia 
William Levine, University of Chicago: The Movement is Everything: Radical Kantianism and the Ideal of Emancipation in Modern Germany

Tejas Parasher, University of Chicago: SelfRule and the State in Indian Political Thought, 1880-1950

Lucas Pinheiro, University of Chicago: Factories of Modernity: Labor, Aesthetics, and the Racial Politics of Historical Capitalism

Michael Rosol, University of Chicago: Weberian Militaries: Promotion and Appointment Systems as a Determinate of Military Effectiveness in Population Centric Counterinsurgency

Megan Savel Hawryluk, University of Chicago: Expectations, Perceptions, and Social Roles: The Effects and Performance of Gender in Campaigns for the United States Congress

Kristina Teater, University of Cincinnati: Using Transnational Advocacy Networks to Challenge Restrictions on Religion: Christian Minorities in Malaysia and India

Brandon Armstrong, University of Florida: An Exploration of Crime and Politics

Asli Baysal, University of Florida: European Democracy in Time: A Historical Institutionalist Approach to Democracy in the European Union

Ross Cotton, University of Florida: The Challengers of Regional Authority: Explaining Regionalist Party Success and Failure in Scotland and Quebec

Amanda Edgell, University of Florida: The Strategic Origins of Electoral Gender Quotas in Authoritarian Regimes

Mary V. Gorham, University of Florida: Recounting the Nation: State, Society, and Nation-Building in Tanzania, Kenya, Singapore, and Malaysia

Enrijeta Shino, University of Florida: Survey Mode Effects: Reshaping Perceptions of the Electorate
Anna Weissman, University of Florida: The Limits of Tolerance: LGBTQ Parenting Rights and the (Re)Production of National Identity in Europe

Ryan Whittingham, University of Florida: Coercion or Accommodation? A Bargaining Theory Explanation of State Repression

Susan Achury, University of Houston: The Impact of Formal Authority in Latin American Constitutional Justice

Haeyong Lim, University of Houston: Three Essays on the Political Economy of Transparency: How Transparency Influences, Investment, and Redistribution

Scott Hofer, University of Houston: Creating Liberal Justice? The Sources of Inequality and Their Moral Weight

Amanda Burke, University of Illinois: Thinking Outside the Box: Extra-Parliamentary Strategies and Their Effects on the Development of Good Governance in New Democracies

Peter Chereson, University of Illinois: The Revolution Will be Made Public: The Effects of International Actors on Protest Movements in Hybrid and Authoritarian Regimes Today

Kyle Estes, University of Illinois: PostSoviet Ethnic Politics and Public Goods Provision

Jillian Evans, University of Illinois: A Primer on Primaries: Exploring the Variation in US Primary Election Laws

Tyler Pack, University of Illinois: Dangerous Neighborhoods: Threats and Opportunities from Nearby Civil Wars

Michael Uhall, University of Illinois: On the Political Uses of Creative Darkness: Freedom, Subjectivity, and Normativity

Charla Waeiss, University of Illinois: Information and Identities in Dynamic Electoral Environments

Ajar Cherikova, University of Illinois at Chicago: Undocumented Citizens: Legacies of the Propiska System in a Post-Soviet City
Andris Zimelis, University of Illinois at Chicago: An Integrated Approach to Corruption: A Comparative Analysis of Three Cities

Ryan Daugherty, University of Kansas: Challenge of Ethnicity? Ethnic Diversity and Democratic Representation

Alexandra Middlewood, University of Kansas: Female Firepower: Exploring the Politics of Gun Ownership and Gender

Sara Miller, University of Kansas: Collusion or Representation?: The Cartel Party Theory Reexamined

Todd Schmidt, University of Kansas: Silent Coup of the Guardians: The Influence of U.S. Military Elites on National Security

Stephen Joiner, University of Kentucky: Piecing Together Coalition War: Threat, Politics, and Coalition Structure

Christopher Ledford, University of Kentucky: Seeds of Suspicion

Gregory Saxton, University of Kentucky: Perceptions of Fairness and Political Support in the Face of Economic Inequality

Trey Billing, University of Maryland, College Park: The Demand for Aid and the Politics Development in Africa

Heather Hicks, University of Maryland, College Park: Intersectional Stereotyping in Political Campaigns

Arthur Leaderman, University of Maryland, College Park: Overcoming NonCooperation: Designing a Patent System for the Public

Jacob Lewis, University of Maryland, College Park: Corruption, Reform, and Revolution in Africa's Third Wave of Protest

Jared McDonald, University of Maryland, College Park: Empathy and Electoral Accountability

Allison Patch, University of Maryland, College Park: Electoral Loss and Contention 
Sebastian Vallejo Vera, University of Maryland, College Park: By Invitation Only: On How Interest Groups Want to Affect Policy and Why Do Politicians Bring Them into Committees.

Lucas A. Franco, University of Minnesota: Organizing the Fissured Workplace: The Fight to Cultivate Collective Worker Power in an Era of Nonstandard Work

Elena Gambino, University of Minnesota: "Presence in Our Own Land:" Second Wave Feminism and the Lesbian Body Politic

Jennifer Halen, University of Minnesota: Algorithmic Interventions: The Power and Politics of Algorithmic Decision Systems

Elif Kalaycioglu, University of Minnesota: Possibilities of Global Governance: World Heritage and the Politics of Universal Value and Expertise

Florencia Montal, University of Minnesota: Rage Against the Regime: Policy Responses to International Investment Arbitration

Ahmad Qais Munhazim, University of Minnesota: "Queering Borders": War, Diaspora, Gender and Sexuality among Afghans in the United States

Avram E. Munoz, University of Minnesota: The Congressional Hispanic Caucus and the Coalitional Representation of Latinxs in the U.S. House of Representatives

Nate Andrew, University of Mississippi: Changing Power Distributions and Economic Foreign Policy

Jeremy Cox, University of Mississippi: Social Identity, Economic Interests, and the Formation of Host Attitudes Towards Refugees

Daniel Fudge, University of Mississippi: The Politics of Place, the Urban-Rural Divide, and Geographic Identities in American Politics

Dana Angello, University of Missouri: What Determines Vote Share in City Council Elections? The Incumbency Advantage and Economic Voting
Adriana Boersner, University of Missouri: Personalist Dictators and the Choice of Military Intervention in Civil Conflicts

Saumil Dharia, University of Missouri: Dangerous Weapons: Arms Transfer, Interstate Conflict, and Dependence

Michael Hendricks, University of Missouri: Resource Extraction, Resistance, and Religion in Nicaragua

Joshua Holzer, University of Missouri: Human Rights in Presidential Democracies: Does a Runoff Rule Reduce Repression?

Aaron Kushner, University of Missouri: Ruling or Being Ruled? The Development of Citizenship in the Cherokee Nation

Katherine Perry, University of Missouri: Feeding the Beast: Macroeconomic Drivers of Leadership Responses to Foreign Policy Action and the Gendered Consequences for Human Trafficking

Tiffanesha Williams, University of Missouri: Colonial Inclusivity: Historical Education and State Capacity in Post-Colonial States

Emir Yazici, University of Missouri: Transborder Ethnic Alignments and the Interplay between Domestic and International Violence

Joseph Anthony, University of MissouriSt. Louis: Party Blight in Rural Missouri: Causes and Consequences of Local Organizational Decline

Kerra McCorkle-Akanbi, University of Missouri-St. Louis: The Influence of Media Consumption on Trust, Political Efficacy and Social Media Activism among Young Adults

Ameena Zia, University of Missouri-St. Louis: Descriptive to Substantive Representation: A Study of Gender Quotas in the National Assembly of Pakistan, 2002-2018

Dennis Crawford, University of NebraskaLincoln: Cruising into Conflict: A Mixed Methods Examination of Cruise Missile Possession and the Initiation of Military Force
Matthew Eberhart, University of Nebraska-Lincoln: Inconsistent Interventions? The Effect of Operational Feasibility on US Presidential Military Intervention Decisions

Jeonhyeon Kim, University of NebraskaLincoln: At the Border of Human Rights: Analyzing State Compliance with International Refugee Protection Norms

Julia Reilly, University of NebraskaLincoln: The Prosecution Paradox: How the International Criminal Court Affects Civil War Peace Negotiations

Jonathan Bradley, University of Nevada, Las Vegas: Religion as a Political Tool: The Use of Religious Frames by Politicians in the US House of Representatives, 2011-2017

Hafthor Erlingsson, University of Nevada, Las Vegas: External Voting in Developing Countries: Strategic Bargaining and the Role of Remittances

Victor Fakoya, University of Nevada, Las Vegas: Ethnic Power Dominance in a Resource-Rich Sub Saharan African State: An Analysis of Violent Conflict Accelerators and the Mitigating Influence of Civil Society in Nigeria

Bernadette Lazar, University of Nevada, Las Vegas: The Sisterhood of Transnational Feminism: An Examination of Iran and Argentina

Roman Lewis, University of Nevada, Las Vegas: States, Satellites, and International Crisis Behavior

Jason Mitchell, University of Nevada, Las Vegas: Nonstate Actors and International Law: Just War Theory or the Universal Declaration of Human Rights?

Rafael Oganesyan, University of Nevada, Las Vegas: The Post-Soviet Voter: Evidence From The Caucasus

Michael Trevathan, University of Nevada, Las Vegas: Turbulent Waters: Navigating the Maelstrom of Water Insecurity and Ethno-Environmental Conflict 
Donald Utchel, University of Nevada, Las Vegas: The Parallel Security Apparatus: Examining the Cases of Baathist Iraq, Syria, and Iran

Travis Hagner, University of Nevada, Reno: Developing a Virtual Constituency

Lucia Bird, University of North Carolina, Chapel Hill: Transnational Contentious Politics: The Role of Diasporas in Civil Conflicts

John Curiel, University of North Carolina, Chapel Hill: Redistricting Cartels and Overlapping Ambition

Cole Harvey, University of North Carolina, Chapel Hill: The Machinery of Manipulation: A Comparative Analysis of Principal-Agent Relationships and Electoral Manipulation in Russia, Ukraine and Mexico

Jelle Koedam, University of North Carolina, Chapel Hill: Multidimensional Party Competition: Stability and Change in European Party Systems

John-Paul Petrash, University of North Carolina, Chapel Hill: A Sociospatial Analysis of Student Groups on University Campuses: Toward Capacious Campus Pluralism Rooted in Meaningful Association

Amy Sentementes, University of North Carolina, Chapel Hill: The Psychology of Social Group Issue Relations

Serge Severenchuk, University of North Carolina, Chapel Hill: Polarization and Partisan Bias

Steven Sparks, University of North Carolina, Chapel Hill: Consequences of the Top-Two Primary Reform

Bryan Velarde, University of North Carolina, Chapel Hill: The American Military-Industrial Compensation Hypothesis

James Mitchell Watkins, University of North Carolina, Chapel Hill: Essays on Foreign Aid and Governance
Rob Williams, University of North Carolina, Chapel Hill: The Geography of Secession

Ryan Williams, University of North Carolina, Chapel Hill: The Consequences of Specialization: Decision Making in US Federal Specialized Courts

Ayal Feinberg, University of North Texas: Expaining the Homeland: Diaspora Nexus: Israel-Motivated Violence and Its Consequences

Mustafa Kirisci, University of North Texas: State Capacity, Security Forces, and Terrorist Group Termination

Roman Krastev, University of North Texas: Identity Claims and Leaders Survival

Melissa McKay, University of North Texas: Making it Personal: The Psychological Lifecycle of Witnessing Before the ICTY

Chris Pace, University of North Texas: Nations at War: How External Threat Affects Ethics Politics

Tyler Yates, University of North Texas: Institutionalizing Atrocity: An Analysis of Civil War Legacy, Post-Conflict Governance, and State Behavior

Mark Brockway, University of Notre Dame: Secular Activism in Party Politics

Jonathan Gondelman, University if Notre Dame: Thucydides and the Passions of City Life

M. Tahir Kilavuz, University of Notre Dame: Authoritarian Persistence and Regime Change in the Middle East and North Africa: Autocrats, Opposition, and Coalitions

Maryann Kwakwa, University of Notre Dame: The Ambiguous Cohort: How Alternative Undergraduate Experiences Impact Civic Engagement

Minju Kwon, University of Notre Dame: Blacklisted Rebels: Commitment to Child Rights in Armed Conflict

Emily Maiden, University of Notre Dame: Beware the Magic Crocodile: The Role of Chiefs in Cultural and Political Reform in Malawi
Lucia Tiscornia Martinez, University of Notre Dame: Who Calls the Shots? Police Reform and Organized Criminal Violence in the Aftermath of Armed Conflict

Colleen Mitchell, University of Notre Dame: The Political Lessons of Rome: Augustine and Machiavelli on the Eternal City

Sidney Simpson, University of Notre Dame: Turning Against Oneself: The Internalization of the Subject and the Critique of Culture

Robert Wyllie, University of Notre Dame: Envy in Spinoza's Political Science

Tracey Bark, University of Oklahoma: Bureaucracies and the Supply of Information in Higher Education Policy

Elizabeth Bell, University of Oklahoma: Free College For Whom? How Politics, Policy Design, and Public Management Shapes Program Access and Success

Dylan Billings, University of Oklahoma: Examining The Effects of Economic Knowledge on Political Judgements

Andrew Fox, University of Oklahoma: Strings of Traitors: Social Networks and the Organizational Trajectory of the Khmer Rouge

Wesley Wehde, University of Oklahoma: From The Mundane To The Profound: Developing A Political Model of Weather Information Processing and Climate Change Beliefs

Crystal Brown, University of Oregon: Never at Home: Immigrant Integration in Denmark and Sweden

Yongwoo Jeung, University of Oregon: Political Economy of Race in the US Labor Market in the 1960 s

Jessica Neafie, University of Oregon: Investigating the Effects of the Global Economy on Policy and Practice in Developing Countries: Foreign Direct Investment and the Environment 
Vivienne Born, University of Pennsylvania: Getting the Best of Us: Multinational Corporate Networks and the Diffusion of Skill-Selective Immigration Policies

Keith Carter, University of Pennsylvania: Great Power, Arms, and Alliances

Victoria Gilbert, University of Pennsylvania: Identity in the Wake of the State: Local, National, and Supranational Dynamics of the Syrian Conflict

Ashley Gorham, University of Pennsylvania: Information and Democracy: Lessons from the Hacktivists

Emma Hayward, University of Pennsylvania: States and Group Rights: Legal Pluralism and the Decentralization of Judicial Power

Chris Liu, University of Pennsylvania: Information and International Conflict

Patricia Posey, University of Pennsylvania: Refinancing the American Dream: the Consequences of Targeted Financial Policy for Political and Racial Inequality in the United States

Javier Revelo-Rebolledo, University of Pennsylvania: The Political Economy of Amazon Deforestation: Subnational Development and the Uneven Reach of the Colombian State

Travis Robison, University of Pennsylvania: Security with Solvency: Retrenchment and Strategic Reorientation

Jeremy Springman, University of Pennsylvania: Off the Hook? The Impact of NGO Service Provision on Domestic Politics

Ruolin Su, University of Pennsylvania: Violence at Home or Abroad: Understanding How Rebel Leaders Respond to Domestic Unrest

Joanna Wuest, University of Pennsylvania: Born This Way: Scientific Authority and Citizenship in the American LGBTQ Movement

Yu Zeng, University of Pennsylvania: Learning to Reform: The Politics of Land Market Reform in China
Emiel Awad, University of Rochester: Persuasion and Design in Organizations

Gleason Judd, University of Rochester: Essays on Democratic Institutions

Shichao Ma, University of Rochester: Three Essays on Electoral Rules and Competitive Authoritarian Elections

Andrea Morris, University of Rochester: Essays on Islamic State Foreign Fighters

Sara Sadhwani, University of Southern California: Descriptive Representation in a Multiracial Era

Danilo Buscatto Medeiros, University of Virginia: Extremism and Polarization: How Income Inequality Affects Legislative Behavior in Brazil

Rafael Lopez, University of Virginia: Innovating in War: Risk, Organizational Cost and Successful Adoption

Jacobs Nicholas, University of Virginia: Presidential Federalism: Executive Power, Administrative Decentralization, and the Transformation of America's Compound Republic

Anthony Sparacino, University of Virginia: The Democratic and Republican Governors Associations and the Nationalization of American Politics

Elizabeth Chrun, University of Washington: Anticorruption Agencies in Democracies

Sarah Drier, University of Washington: Church, State and Sex: How Africa's Transnational Churches Shape Human Rights

David Lopez, University of Washington: State Building, Elite Ideology, and Mass Schooling: The Formation of Education Leviathans in Europe and the Americas, 1800 to 1970

Nora Webb Williams, University of Washington: Colonial Policy, Social Trust, and Economic Resilience: The Longterm Impacts of Imperial Russian Settlement in Southern Kazakhstan
Daniel Yoo, University of Washington: Development Aid, Institutional Change, and Local Democracy: Investigating the Role and Impact of Elected Councils in Rural Indonesia

Oscar Castorena, Vanderbilt University: Essays on Political Representation and Accountability in Mexico

Maggie Deichert, Vanderbilt University: Partisan Cultural Stereotypes: The Effect of Everyday Partisan Associations on Social Life in the United States

Andrew Englehardt, Vanderbilt University: The Race Politics Makes: Parties, Polarization, and Whites' Racial Attitudes

Marc Trussler, Vanderbilt University: The Impact of High Information Environments on Representation in the US House of Representatives

Sheahan Virgin, Vanderbilt University: Extra-Partisan Electoral Reform in the US: The Effects of Geographic Self-Interest, Core Values, and American Exceptionalism on Electoral Rule Choice

James Brandell, Virginia Tech: An Evaluation of how Federal Advisory Boards Operationalize Congressional Intent of Transparency, Financial Efficiency, and Balanced Membership

Kathryn Buechel, Virginia Tech: Institutional Adaptation and Public Policy Practices of Military Transfer Credit

Lorita Daniels, Virginia Tech: Illuminating Identities and Motivations in Public Participation: Administrators in Local Government

Khushboo Gupta, Virginia Tech: The Indian Perspective of Smart Cities

Faith Hubbard, Virginia Tech: Beyond the Boundaries: A Sharing of Power in Processes of Public Education Decisionmaking and Planning

Rosa Krewson, Virginia Tech: US Military Student Veterans Identity Formation: Policy Feedback and Symbolic Interactionism 
Huyen Thi Khanh Le, Virginia Tech: Emotional Agents: Modeling Travel Satisfaction, Affinity, and Travel Demand Using a Smartphone Travel Survey

Kimberly Le, Virginia Tech: Organizing Freedom: Collaboration with the Freedmen's Bureau in the Early Years of Reconstruction

Sarah E. Lyon-Hill, Virginia Tech: A New Institutionalist History of Appalshop: Exploring the Agential Dynamics of an Appalachian Community Cultural Development Organization

Omchand Mahdu, Virginia Tech: The Impacts of Climate Change on Rice Production and Small Farmers' Adaptation: A Case of Guyana

Anne Walters, Virginia Tech: The Impact of Advocacy Groups in Facilitating Policy Diffusion to Pass Paid Sick Leave Laws in New Jersey

Rongrong Wei, Virginia Tech: Local Fiscal Sustainability within American Federalism

Ermira Babamusta, West Virginia University: Political Trust in Kosovo: Exploring Cultural and Institutional Dynamics

Samuel Darkwa, West Virginia University: A Coordination-Based Approach to Subnational Variations in Split-Ticket Voting: The Case of Ghana 1996-2016

Kara Fisher, West Virginia University: Following the Leaders: Issue Attention and Agenda Dynamics in Women's Health Care Policy

Chris Moss, West Virginia University: The Politics of Drug Courts 